\title{
ROBO1 Gene
}

National Cancer Institute

\section{Source}

National Cancer Institute. ROBO1 Gene. NCI Thesaurus. Code C126588.

This gene is involved in neuroblast migration and axon guidance. 